\title{
How much oxygen in adult cardiac arrest?
}

\author{
Antonio Maria Dell'Anna, Irene Lamanna, Jean-Louis Vincent and Fabio Silvio Taccone* \\ See related commentary by Gershengorn, http://ccforum.com/content/18/5/556
}

\begin{abstract}
Although experimental studies have suggested that a high arterial oxygen pressure $\left(\mathrm{PaO}_{2}\right)$ might aggravate post-anoxic brain injury, clinical studies in patients resuscitated from cardiac arrest (CA) have given conflicting results. Some studies found that a $\mathrm{PaO}_{2}$ of more than $300 \mathrm{~mm} \mathrm{Hg}$ (hyperoxemia) was an independent predictor of poor outcome, but others reported no association between blood oxygenation and neurological recovery in this setting. In this article, we review the potential mechanisms of oxygen toxicity after CA, animal data available in this field, and key human studies dealing with the impact of oxygen management in CA patients, highlighting some potential confounders and limitations and indicating future areas of research in this field. From the currently available literature, high oxygen concentrations during cardiopulmonary resuscitation seem preferable, whereas hyperoxemia should be avoided in the post-CA care. A specific threshold for oxygen toxicity has not yet been identified. The mechanisms of oxygen toxicity after CA, such as seizure development, reactive oxygen species production, and the development of organ dysfunction, need to be further evaluated in prospective studies.
\end{abstract}

\section{Introduction}

Sudden cardiac arrest (CA) is the leading cause of death among adults worldwide [1,2]. In most patients, attempts at cardiopulmonary resuscitation (CPR) remain ineffective and spontaneous cardiac activity cannot be restored [3]. Among those patients who do achieve return of spontaneous circulation (ROSC), there are two key periods when death may occur: early (during the first three days), usually because of recurrent $\mathrm{CA}$ or severe cardiovascular failure resulting in multiple organ failure (MOF), and late (beyond day 3), usually secondary to withdrawal of life-sustaining therapies in the absence of neurological recovery [4]. Although several interventions, including target temperature management (TTM), have been introduced into the postCA care of these patients [5,6], conflicting results have been obtained [7], and these approaches are not sufficient to prevent the deleterious consequences of brain ischemia in all patients. During the post-CA care, secondary brain insult must be avoided [8] and optimization of brain oxygenation is likely to be an important component of brain recovery. The restoration of adequate systemic hemodynamics is a prerequisite to provide adequate cerebral blood flow in CA patients $[9,10]$, but brain oxygenation is also determined by

\footnotetext{
* Correspondence: ftaccone@ulb.ac.be

Department of Intensive Care, Erasme Hospital, Université Libre de Bruxelles, Belgium, Route de Lennik 808, 1070 Brussels, Belgium
}

the arterial oxygen content. Arterial oxygen pressure $\left(\mathrm{PaO}_{2}\right)$ itself may influence brain cellular oxygen supply; if hypoxemia (that is, $\mathrm{PaO}_{2}$ of less than $60 \mathrm{~mm} \mathrm{Hg}$ ) is associated with poor outcomes after CA [11], a high $\mathrm{PaO}_{2}$ may also be detrimental in a vulnerable brain, as suggested in patients with traumatic brain injury or stroke $[12,13]$. The aims of this article are to review the potential mechanisms of oxygen toxicity after $\mathrm{CA}$ and to discuss the clinical impact of oxygen management on post-CA care.

\section{Post-cardiac arrest syndrome: the role of oxygen}

Post-cardiac arrest syndrome (PCAS) is a complex phenomenon, which shares several features with septic shock $[7,14]$. In particular, PCAS includes a systemic inflammatory response that can be triggered by the ischemia-reperfusion injury and also specific precipitating events, such as concomitant infections or heart disease. Moreover, PCAS can contribute to brain injury and myocardial dysfunction and can rapidly lead to MOF. The primary ischemia-reperfusion injury [15] activates various intracellular pathways, promoting ion concentration disequilibrium with increased intracellular levels of inorganic phosphate, lactate, and $\mathrm{H}^{+}$, and resulting in an influx of calcium into the cell [16], which aggravates mitochondrial dysfunction and eventually leads to programmed cellular death (apoptosis). After reperfusion has 
occurred, other mediators, including superoxide $\left(\mathrm{O}_{2}{ }^{-}\right)$, peroxynitrite $\left(\mathrm{NO}_{2}{ }^{-}\right)$, hydrogen peroxide $\left(\mathrm{H}_{2} \mathrm{O}_{2}\right)$, and hydroxyl radicals $\left(\mathrm{OH}^{-}\right)$, contribute to worsen cellular function by oxidizing and damaging numerous cellular components [17] (Figure 1). These reactive oxygen species (ROS) then have a central role in initiating and enhancing the post-ischemic damage [15]. Indeed, supra-normal oxygen concentrations in this context may further stimulate ROS production and contribute to worsen cellular function in a setting of impaired mitochondrial function and impaired oxygen utilization. Moreover, some other systemic detrimental effects of hyperoxemia have been known for many years [18-20]. Hyperoxemia causes systemic and coronary vasoconstriction, which can decrease cardiac output and induce myocardial ischemia. In some experimental models of global cerebral ischemia, hyperoxemia has been shown to be detrimental to the brain, probably also because of its vasoconstrictor effects [21,22]. Hyperoxemia may also provoke or exacerbate seizures, which could aggravate brain injury $[23,24]$.

\section{Oxygen therapy after cardiac arrest: animal studies}

Several studies have assessed the effects of administering high oxygen concentrations in experimental models of CA. Pilcher and colleagues [25] recently reviewed studies that evaluated the role of different oxygenation strategies that is, one with $100 \%$ inspired oxygen fraction $\left(\mathrm{FiO}_{2}\right)$ and the other with lower $\mathrm{FiO}_{2}$ as a control - after ROSC. Six studies including 95 animals of different species were included in their final meta-analysis; in general, administration of high $\mathrm{FiO}_{2}(100 \%)$ for 1 hour after ROSC resulted in a worse neurological outcome, as assessed by a neurological deficit score, than other $\mathrm{FiO}_{2}$ values. Four of the five studies that assessed histological damage reported a significantly higher neuronal injury with high $\mathrm{FiO}_{2}$; cerebral metabolic function was also more altered in the high $\mathrm{FiO}_{2}$ group. The extrapolation of such findings to humans, however, may be misleading. First, in all of these experimental studies, the animals were already mechanically ventilated before $\mathrm{CA}$, and this is not usually the case in humans; also, control animals did not all receive the same $\mathrm{FiO}_{2}$ (ranging from 21\% to higher levels based on $\mathrm{PaO}_{2}$ values), and the intervention period was rather short (that is, 1 hour). Moreover, different models of CA were employed (that is, asphyxia versus electrical-induced ventricular fibrillation), with shorter durations of CPR than in humans, and in some articles clear $\mathrm{PaO}_{2}$ targets were aimed at, whereas in others only $\mathrm{FiO}_{2}$ was modified without looking at $\mathrm{PaO}_{2}$ values. In addition, no potential neuroprotective therapy, such as TTM, was provided, so that its influence cannot be ascertained. In summary, animal data have highlighted a clear correlation between the application of high $\mathrm{FiO}_{2}$ after $\mathrm{CA}$ and poor neurological recovery. Nevertheless, experimental models are quite remote from the human setting, so that the observations cannot be readily translated to humans in the post-CA management.

\section{Oxygen after cardiac arrest: human studies}

Two studies reported conflicting results regarding oxygen management during the early phase of CA (Table 1).

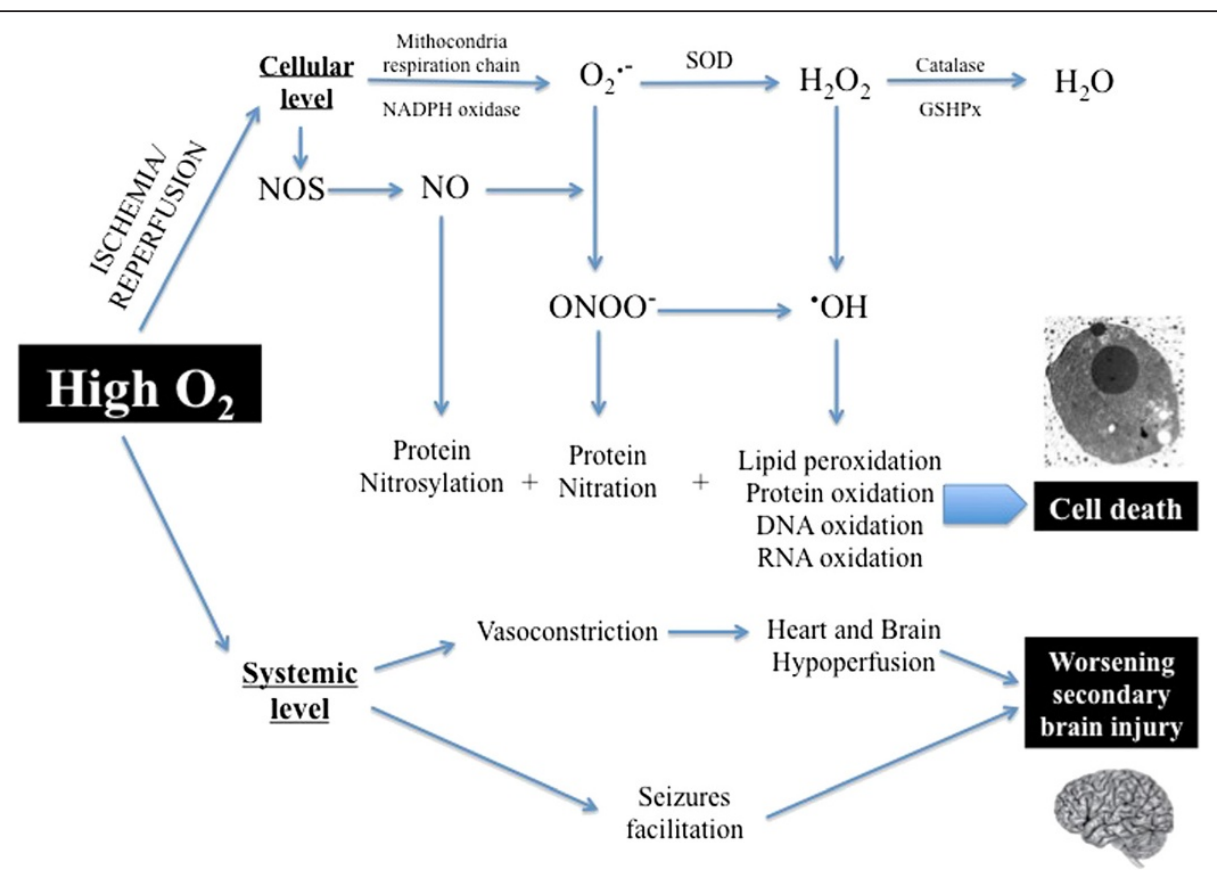

Figure 1 Summary of cellular and systemic effects of high oxygen $\left(\mathrm{O}_{2}\right)$ concentrations. $\mathrm{H}_{2} \mathrm{O}$, water; $\mathrm{H}_{2} \mathrm{O}_{2}$, hydrogen peroxide; $\mathrm{NO}$, nitric oxide; $\mathrm{NOS}$, nitric oxide synthase; $\mathrm{O}_{2}^{--}$, superoxide ion; ${ }^{\circ} \mathrm{OH}$, hydroxide ion; $\mathrm{ONOO}^{-}$, peroxynitrite ion. 
Table 1 Summary of clinical studies evaluating the role of oxygen concentrations on outcome after cardiac arrest

\begin{tabular}{|c|c|c|c|c|c|c|c|c|c|}
\hline Reference & Type & Patients (period)\% of HO & OHCA & Definition $\mathrm{HO}$ & Evaluation & TH $(\%$ treated $)$ & Cutoff $^{a}$ & Outcome & Main results \\
\hline \multicolumn{10}{|l|}{ During CPR } \\
\hline Spindelboeck et al. [26] & $\mathrm{R}$ & 145 (8 years) $14 \%$ & $100 \%$ & $>300$ mm Hg & $\begin{array}{l}\text { During } \\
\text { CPR }\end{array}$ & NA & NR & In-hospital CPC & $\begin{array}{l}\text { Higher rate of hospital admission } \\
\text { in hyperoxemic patients }\end{array}$ \\
\hline \multicolumn{10}{|l|}{ After ROSC } \\
\hline Kuisma et al. [27] & $\mathrm{RCT}$ & 28 (NA) $50 \%$ & $100 \%$ & $\begin{array}{l}1 \text { hour of ventilation at } \\
\qquad \mathrm{FiO}_{2} 100 \%\end{array}$ & $\begin{array}{l}\text { 24- and } \\
\text { 48-hour }\end{array}$ & No (50\%) & No & NSE and S100B & $\begin{array}{c}\text { No difference in biomarkers of } \\
\text { brain injury }\end{array}$ \\
\hline \multicolumn{10}{|l|}{ Post-CA care (ICU stay) } \\
\hline \multirow[t]{2}{*}{ Kilgannon et al. [28] } & \multirow[t]{2}{*}{$R / D$} & \multirow[t]{2}{*}{6,326 (5 years) $18 \%$} & \multirow[t]{2}{*}{$43 \%$} & \multirow[t]{2}{*}{ First ABG $>300 \mathrm{~mm} \mathrm{Hg}$} & \multirow[t]{2}{*}{ 24-hour } & \multirow[t]{2}{*}{$N R \approx 6 \%$} & \multirow[t]{2}{*}{ No } & In-hospital death & \multirow{2}{*}{$\begin{array}{l}\text { Increased hospital mortality in } \\
\text { hyperoxemic patients }\end{array}$} \\
\hline & & & & & & & & $\begin{array}{l}\text { Neurological } \\
\text { function }\end{array}$ & \\
\hline \multirow[t]{2}{*}{ Kilgannon et al. [29] } & \multirow[t]{2}{*}{ R/D } & \multirow[t]{2}{*}{4,459 (5 years) $18 \%$} & \multirow[t]{2}{*}{$45 \%$} & \multirow[t]{2}{*}{ First ABG } & \multirow[t]{2}{*}{ 24-hour } & \multirow[t]{2}{*}{$N R \approx 6 \%$} & \multirow[t]{2}{*}{ No } & In-hospital death & \multirow{2}{*}{$\begin{array}{l}\text { Increased hospital mortality for } \\
\text { every } 100 \mathrm{~mm} \mathrm{Hg} \text { increase } \\
\text { in } \mathrm{PaO}_{2}\end{array}$} \\
\hline & & & & & & & & $\begin{array}{l}\text { Neurological } \\
\text { function }\end{array}$ & \\
\hline Bellomo et al. [31] & $R / D$ & 12,108 (10 years) $11 \%$ & $68 \%$ & Worst (A-a) $\Delta \mathrm{O}_{2}>300 \mathrm{~mm} \mathrm{Hg}$ & 24-hour & $N R \approx 33 \%$ & No & In-hospital death ${ }^{b}$ & $\begin{array}{l}\text { Hyperoxemia did not affect } \\
\text { outcome when adjusted for } \\
\text { several confounders. }\end{array}$ \\
\hline \multirow[t]{2}{*}{ Janz et al. [32] } & \multirow[t]{2}{*}{$\mathrm{R}$} & \multirow[t]{2}{*}{$170(5$ years $) \approx 25 \%$} & \multirow[t]{2}{*}{$80 \%$} & \multirow[t]{2}{*}{ Highest $\mathrm{PaO}_{2}$} & \multirow[t]{2}{*}{ 24-hour } & \multirow[t]{2}{*}{ Yes } & \multirow[t]{2}{*}{ No } & In-hospital death & \multirow{2}{*}{$\begin{array}{c}\text { Increased hospital mortality for } \\
\text { every } 100 \mathrm{~mm} \mathrm{Hg}^{\text {increase }} \\
\text { in } \mathrm{PaO}_{2}\end{array}$} \\
\hline & & & & & & & & In-hospital CPC & \\
\hline Ihle et al. [33] & R & $584(5$ years $) \approx 6 \%$ & $100 \%$ & Worst (A-a) $\Delta \mathrm{O}_{2}>300 \mathrm{~mm} \mathrm{Hg}$ & 24-hour & NR & No & In-hospital death & Hyperoxemia did not affect outcome. \\
\hline Lee et al. [34] & $\mathrm{R}$ & 213 (4 years) <3\% & $83 \%$ & Mean $\mathrm{PaO}_{2}$ value & 24-hour & Yes & No & In-hospital death & $\begin{array}{l}\text { V-shaped association between } \\
\text { the mean } \mathrm{PaO}_{2} \text { and poor } \\
\text { neurologic outcome at hospital } \\
\text { discharge }\end{array}$ \\
\hline Vaahersalo et al. [35] & $P$ & 409 (1 year) & $100 \%$ & Mean $\mathrm{PaO}_{2}$ value $>300 \mathrm{~mm} \mathrm{Hg}$ & 24-hour & Yes (71\%) & No & 1-year CPC & $\begin{array}{c}\mathrm{PaO}_{2} \text { was not correlated to } \\
\text { outcome }\end{array}$ \\
\hline
\end{tabular}

IIdentification of an arterial oxygen pressure $\left(\mathrm{PaO}_{2}\right)$ threshold to accurately separate patients with good and poor outcome. ${ }^{\mathrm{b}} \mathrm{After}$ adjustment on Acute Physiology and Chronic Health Evaluation III (APACHE III) score. $(\mathrm{A}-\mathrm{a}) \triangle \mathrm{O}_{2}$, alveolo-arterial oxygen difference; $\mathrm{ABG}$, arterial blood gas (analysis); $\mathrm{CA}$, cardiac arrest; $\mathrm{CPC}$, Cerebral Performance Category; $\mathrm{CPR}$, cardiopulmonary resuscitation; $\mathrm{FiO}$, inspired oxygen fraction; $\mathrm{HO}$, hyperoxemia; $\mathrm{NA}$, not available; NR, not reported; NSE, neuron-specific enolase; OHCA, out-of-hospital cardiac arrest; P, prospective; R, retrospective; RCT, randomized clinical trial; R/D, retrospective analysis of database; ROSC, return of spontaneous circulation; $\mathrm{S} 100 \mathrm{~B}$, protein $\mathrm{S} 100 \mathrm{~B} ; \mathrm{TH}$, therapeutic hypothermia. 
In 145 out-of-hospital CA patients, Spindelboeck and colleagues [26] observed that high $\mathrm{PaO}_{2}$ (more than $300 \mathrm{~mm} \mathrm{Hg}$ ) levels during CPR were associated with higher rates of ROSC and intact neurological survival when compared with low $\left(\mathrm{PaO}_{2}\right.$ of less than $\left.60 \mathrm{~mm} \mathrm{Hg}\right)$ and normal $\mathrm{PaO}_{2}$. In contrast, Kuisma and colleagues [27] randomly assigned 28 patients to receive either $30 \%$ or $100 \% \mathrm{FiO}_{2}$ for 1 hour after ROSC; five patients (36\%) in the group with lower $\mathrm{FiO}_{2}$ required an increase in $\mathrm{FiO}_{2}$ to $40 \%$ because oxygen saturation fell below 95\%, according to a standardized protocol. The primary endpoints were biomarker levels of brain injury - that is, neuron-specific enolase (NSE) and S100B - at 24 and 48 hours after ROSC, with no differences in absolute values between the two groups overall. However, in the subgroup of patients who did not undergo TTM, those receiving lower $\mathrm{FiO}_{2}$ had lower NSE levels at 24 hours than the other patients $(7.6 \pm$ 4.2 versus $13.5 \pm 9.6 \mu \mathrm{g} / \mathrm{mL}, P=0.049$ ). Thus, one may argue that high $\mathrm{PaO}_{2}$ during $\mathrm{CPR}$ reflects better lung function or better quality CPR or both, with higher blood flow and better tissue oxygenation (indeed all patients received $\mathrm{FiO}_{2}$ of $100 \%$ ), whereas administration of high $\mathrm{FiO}_{2}$ immediately after ROSC could enhance brain injury. Importantly, the retrospective nature of the study by Spindelboeck and colleagues [26] may have limited the analysis of all factors possibly affecting outcome (that is, quality of CPR, comorbidities, and so on). Also, blood gas analysis samples were drawn within 60 minutes from CPR initiation, and it is difficult to compare patients analyzed in the early CPR with those included in the later phase, who may have developed pulmonary injury with reduced $\mathrm{PaO}_{2}$ due to prolonged resuscitation itself. It is difficult to determine the role of oxygen levels during CPR per se on neurological outcome of CA patients because they may be a surrogate marker of resuscitation performance or better cardiorespiratory status or both. Moreover, brain injury is a continuous process, and the time course of $\mathrm{PaO}_{2}$ may more significantly influence neurological outcome in these patients.

Few clinical studies have evaluated the role of hyperoxemia during the ICU stay on outcome of CA patients. Kilgannon and colleagues published two different analyses on the same large database from a cohort of patients from 131 US hospitals (Increase Minority Participation and Awareness of Clinical Trials (IMPACT) Database). In the first study [28], including 6,326 patients, hospital mortality was higher in patients with hypoxemia (defined as a $\mathrm{PaO}_{2}$ of less than $60 \mathrm{~mm} \mathrm{Hg}$ or altered gas exchange with a $\mathrm{PaO}_{2} / \mathrm{FiO}_{2}$ ratio of less than 300$)$ or hyperoxemia $\left(\mathrm{PaO}_{2}\right.$ of more than $300 \mathrm{~mm} \mathrm{Hg}$ ) detected in the first arterial blood gas (ABG) available within 24 hours after admission, compared with patients with normal oxygen levels (hypoxemia $53 \%$ versus hyperoxemia $67 \%$ versus normoxemia $45 \%, P<0.001)$. In a multivariable logistic regression analysis, hyperoxemia was independently associated with in-hospital mortality: odds ratio (OR) 1.8, 95\% confidence interval (CI) 1.5 to 2.2. In the second study, after exclusion of patients with hypoxemia, the investigators wanted to evaluate the association between $\mathrm{PaO}_{2}$, considered as a continuous variable, and in-hospital mortality [29]. In the 4,459 patients studied, the median $\mathrm{PaO}_{2}$ was 231 (interquartile range 149 to 349$) \mathrm{mm} \mathrm{Hg}$ and in-hospital mortality was $54 \%$. Multivariable analysis yielded a significant $6 \%$ increase in mortality for any $\mathrm{PaO}_{2}$ increase by $25 \mathrm{~mm} \mathrm{Hg}$ (OR 1.06, 95\% CI 1.05 to 1.07). Although these two studies support the hypothesis that hyperoxemia is associated with worse outcome after $\mathrm{CA}$, some limitations must be acknowledged. First, only a small proportion of patients were treated with hypothermia. Second, the use of the $\mathrm{PaO}_{2} /$ $\mathrm{FiO}_{2}$ ratio does not really reflect hypoxemia, because it is a surrogate of lung failure rather than of low arterial oxygen content. Third, data were not collected following the Utstein style [30] or corrected for severity of disease (for example, Acute Physiology and Chronic Health Evaluation III, or APACHE III). Finally, and even more importantly, only the first ABG was taken into account in the final analysis instead of a mean value over the first 24 hours, which might be more representative of real oxygen exposure during this crucial period.

In a large Australian database (Australian and New Zealand Intensive Care Society-Adult Patient Database, or ANZICS-APD), Bellomo and colleagues [31] evaluated the correlation between different $\mathrm{PaO}_{2}$ levels and hospital mortality in 12,108 patients. Although these authors used the same definitions of hypoxemia and hyperoxemia used in previous studies $[28,29]$, they reported a lower percentage of patients with hyperoxemia (11\% [31] versus $18 \%$ [28]) but still a higher mortality rate for patients with hyperoxemia (59\%) and hypoxemia (60\%) when compared with normoxic patients (47\%). In a multivariable model including some major confounding factors, hyperoxemia was significantly associated with mortality (OR 1.2, 95\% CI 1.1 to 1.6); however, in a Cox proportional hazards regression model, after adjustment for other relevant covariates (year of admission, treatment limitations, patient's lowest glucose level in the first 24 hours, patient's indigenous status, and hospital source from home), $\mathrm{PaO}_{2}$ was no longer statistically associated with poor outcome (hazard ratio $1.1,95 \%$ CI 1.0 to $1.2 ; P=0.20$ ). Despite the limitation of a retrospective analysis, this study highlights that some confounders not taken into account in previous studies may have influenced the statistical association between high $\mathrm{PaO}_{2}$ and poor outcome. Importantly, other issues may further limit the power of these findings. The $\mathrm{PaO}_{2}$ from the ABG analysis associated with the worst alveolo-arterial oxygen difference was used, and this $\mathrm{PaO}_{2}$ correlated only fairly with the mean $\mathrm{PaO}_{2}$ (as shown in the analysis of a subgroup of patients) and may not have adequately reflected the exposure of patients to high 
oxygen concentrations. This observation was also suggested by the lower $\mathrm{PaO}_{2}$ values recorded in this study when compared with previous publications (112 versus $231 \mathrm{~mm} \mathrm{Hg}$ ) [29]. Also, no data on neurological outcomes were reported. Finally, as in previous studies, only a minority of patients underwent hypothermia, but cooling is considered to mitigate ROS production and possibly influence hyperoxemia-mediated brain injury [8].

The first article to include patients treated with hypothermia [32] showed that those with a poor outcome had higher $\mathrm{PaO}_{2}$ values than others (254 versus $198 \mathrm{~mm} \mathrm{Hg}$; $P=0.022$ ). A multivariable regression model, including factors known to be associated with poor outcome after $\mathrm{CA}$, confirmed an independent correlation of $\mathrm{PaO}_{2}$ with mortality (OR for a $\mathrm{PaO}_{2}$ increment of every $100 \mathrm{~mm} \mathrm{Hg}$ above $54 \mathrm{~mm} \mathrm{Hg} \mathrm{1.48,95 \%} \mathrm{CI} 1.03$ to 2.01 ) and worse neurological outcome (OR 1.48, 95\% CI 1.03 to 2.14 ) at hospital discharge; however, neither $\mathrm{FiO}_{2}$ nor APACHE III score was included in the final analysis. Unfortunately, no specific cutoff of $\mathrm{PaO}_{2}$ was identified to predict poor outcome, although a $\mathrm{PaO}_{2}$ of more than $228 \mathrm{~mm} \mathrm{Hg}$ was associated with a lower likelihood of neurological recovery. More recently, Ihle and colleagues [33] reviewed 584 patients selected from the ANZICS-APD database, for whom variables could be found following the Utstein model [30]. Unadjusted in-hospital mortality did not differ across different $\mathrm{PaO}_{2}$ ranges (51\% hypoxia, 41\% normoxia, and $47 \%$ hyperoxia; $P=0.28$ ). In a multivariable model including CA characteristics, neither hypoxemia nor hyperoxemia was an independent predictor of in-hospital mortality. In a retrospective cohort of 213 adult patients with $\mathrm{CA}$, Lee and colleagues [34] reported that $\mathrm{PaO}_{2}$ obtained during the first 24 hours was not related to hospital mortality or neurological outcome. In a multivariable model adjusted for established confounding factors after $\mathrm{CA}$, the authors showed a V-shaped relationship between $\mathrm{PaO}_{2}$ and neurological outcome, with the highest probability of good neurologic outcome at $\mathrm{PaO}_{2}$ around $130 \mathrm{~mm} \mathrm{Hg}$. Finally, in a prospective observational study ( $n=409)$, Vaahersalo and colleagues [35] calculated the proportion of time spent in different oxygen categories (less than $75 \mathrm{~mm} \mathrm{Hg}, 75$ to $150 \mathrm{~mm} \mathrm{Hg}, 150$ to $225 \mathrm{~mm}$ $\mathrm{Hg}$, and more than $225 \mathrm{~mm} \mathrm{Hg}$ ) during the first 24 hours after CA. The proportion of time spent with a $\mathrm{PaO}_{2}$ of more than $225 \mathrm{~mm} \mathrm{Hg}$ was similar between groups, as was the association of time within different $\mathrm{PaO}_{2}$ categories and outcome. Mean and highest $\mathrm{PaO}_{2}$ values were higher in patients with good neurological outcome than in those with poor neurological outcome (120 versus $113 \mathrm{~mm} \mathrm{Hg}$ and 173 versus $150 \mathrm{~mm} \mathrm{Hg}$, respectively). Interestingly, the proportion of patients with good neurological outcome was higher in patients with the combination of high mean $\mathrm{PaO}_{2}$ and $\mathrm{PaCO}_{2}$ values.

\section{Perspectives and conclusions}

The International Liaison Committee on Resuscitation states that oxygen administration should be titrated to obtain an oxygen saturation of $94 \%$ to $96 \%$ after ROSC [36]. Thus, routine administration of an $\mathrm{FiO}_{2}$ of $100 \%$ is no longer recommended after CPR [36,37]; however, it still seems prudent to use $100 \%$ oxygen during CPR, although the impact of high $\mathrm{PaO}_{2}$ on survival needs to be further evaluated. Although some studies have suggested that hyperoxemia after CA should be considered a cost-free, potentially modifiable risk factor for poor outcome, many potential confounders have been identified and strongly challenge this concept. Moreover, it is very difficult to identify a specific threshold of toxicity, as most of the studies used a $\mathrm{PaO}_{2}$ of more than $300 \mathrm{~mm} \mathrm{Hg}$ to define hyperoxemia, while some brain injury may also potentially occur at lower values. Also, when a single ABG value was used, the proportion of patients with hyperoxemia ranged from $3 \%$ to $25 \%$ in the different studies [27-29,31-34]. Nevertheless, when all ABG values are considered, the incidence of hyperoxemia may exceed $40 \%$ [38], so that the real impact of exposure to high oxygen concentrations has probably been underestimated. Other parameters obtained from the ABG, such as acidemia or hypocapnia, may also be important determinants of poor outcome after CA $[39,40]$; however, these variables were not considered in these studies. Importantly, it is worthwhile to prospectively evaluate the mechanisms of oxygen toxicity after CA, such as seizure development, ROS production, impaired microcirculation, or the development of organ dysfunction. Finally, further studies are needed to help understand whether an absolute $\mathrm{PaO}_{2}$ value (that is, 'peak') could be more detrimental than a continuous exposure above a specific threshold and to assess the impact of the timing of hyperoxemia occurrence (early versus late phase after arrest) or of variability in oxygen levels (that is, from hypoxemia to hyperoxemia) in this setting.

\section{Key messages}

- Hyperoxemia may potentially exacerbate or aggravate brain injury after experimental cardiac arrest.

- Hyperoxemia has been associated with controversial results in humans.

- Administering high $\mathrm{FiO}_{2}$ (100\%) during CPR still seems to be advisable because it may facilitate ROSC.

- Because of the limited benefit of maintaining potentially harmful supra-normal oxygen levels in such patients, mechanical ventilation should be titrated to maintain an oxygen saturation between $94 \%$ and $96 \%$ in most patients after ROSC. 


\section{Abbreviations}

ABG: Arterial blood gas; ANZICS-APD: Australian and New Zealand Intensive Care Society-Adult Patient Database; APACHE III: Acute Physiology and Chronic Health Evaluation III; CA: Cardiac arrest; Cl: Confidence interval; CPR: Cardiopulmonary resuscitation; $\mathrm{FiO}_{2}$ : Inspired oxygen fraction; MOF: Multiple organ failure; NSE: Neuron-specific enolase; OR: Odds ratio; $\mathrm{PaO}_{2}$ : Arterial oxygen pressure; PCAS: Post-cardiac arrest syndrome; ROS: Reactive oxygen species; ROSC: Return of spontaneous circulation; TTM: Target temperature management.

\section{Competing interests}

The authors declare that they have no competing interests.

\section{Authors' contributions}

FST and AMDA helped to conceive the manuscript, participated in the data collection, and helped to draft the manuscript. IL participated in the data collection and helped to critically revise the manuscript. JLV helped to critically revise the manuscript. All authors read and approved the final version of the manuscript.

\section{Acknowledgments}

This article is based on a lecture given by FST during the 26th Annual Congress of the European Society of Intensive Care Medicine (Paris, October 2013).

\section{Published: 7 October 2014}

\section{References}

1. Nichol G, Thomas E, Callaway CW, Hedges J, Powell JL, Aufderheide TP, Rea T, Lowe R, Brown T, Dreyer J, Davis D, Idris A, Stiell I: Regional variation in out-of-hospital cardiac arrest incidence and outcome. JAMA 2008, 300:1423-1431.

2. Atwood C, Eisenberg MS, Herlitz J, Rea TD: Incidence of EMS-treated out-of-hospital cardiac arrest in Europe. Resuscitation 2005, 67:75-80.

3. Goto Y, Maeda T, Nakatsu-Goto Y: Neurological outcomes in patients transported to hospital without a prehospital return of spontaneous circulation after cardiac arrest. Crit Care 2013, 17:R274

4. Lemiale V, Dumas F, Mongardon N, Giovanetti O, Charpentier J, Chiche JD, Carli P, Mira JP, Nolan J, Cariou A: Intensive care unit mortality after cardiac arrest: the relative contribution of shock and brain injury in a large cohort. Intensive Care Med 2013, 39:1972-1980.

5. Bernard SA, Gray TW, Buist MD, Jones BM, Silvester W, Gutteridge G, Smith K: Treatment of comatose survivors of out-of-hospital cardiac arrest with induced hypothermia. N Engl J Med 2002, 346:557-563.

6. Hypothermia after Cardiac Arrest Study Group: Mild therapeutic hypothermia to improve the neurologic outcome after cardiac arrest. N Engl J Med 2002, 346:549-556.

7. Nielsen N, Wetterslev J, Cronberg T, Erlinge D, Gasche Y, Hassager C, Horn J, Hovdenes J, Kjaergaard J, Kuiper M, Pellis T, Stammet P, Wanscher M, Wise MP, Åneman A, Al-Subaie N, Boesgaard S, Bro-Jeppesen J, Brunetti I, Bugge JF, Hingston CD, Juffermans NP, Koopmans M, Køber L, Langørgen J, Lilja G, Møller JE, Rundgren M, Rylander C, Smid O, et al: Targeted temperature management at $33^{\circ} \mathrm{C}$ versus $36^{\circ} \mathrm{C}$ after cardiac arrest. N Engl J Med 2013, 369:2197-2206.

8. Nolan JP, Neumar RW, Adrie C, Aibiki M, Berg RA, Bottiger BW, Callaway C, Clark RS, Geocadin RG, Jauch EC, Kern KB, Laurent I, Longstreth WT, Merchant RM, Morley P, Morrison LJ, Nadkarni V, Peberdy MA, Rivers EP, Rodriguez-Nunez A, Sellke FW, Spaulding C, Sunde K, Vanden Hoek T: Post-cardiac arrest syndrome: epidemiology, pathophysiology, treatment, and prognostication. A Scientific Statement from the International Liaison Committee on Resuscitation; the American Heart Association Emergency Cardiovascular Care Committee; the Council on Cardiovascular Surgery and Anesthesia; the Council on Cardiopulmonary, Perioperative, and Critical Care; the Council on Clinical Cardiology; the Council on Stroke. Resuscitation 2008, 79:350-379.

9. Bisschops LL, van der Hoeven JG, Hoedemaekers CW: Effects of prolonged mild hypothermia on cerebral blood flow after cardiac arrest. Crit Care Med 2012, 40:2362-2367.

10. Lee JK, Brady KM, Mytar JO, Kibler KK, Carter EL, Hirsch KG, Hogue CW, Easley RB, Jordan LC, Smielewski P, Czosnyka M, Shaffner DH, Koehler RC: Cerebral blood flow and cerebrovascular autoregulation in a swine model of pediatric cardiac arrest and hypothermia. Crit Care Med 2011, 39:2337-2345

11. Yan EB, Hellewell SC, Bellander BM, Agyapomaa DA, Morganti-Kossmann MC: Post-traumatic hypoxia exacerbates neurological deficit, neuroinflammation and cerebral metabolism in rats with diffuse traumatic brain injury. J Neuroinflamm 2011, 8:147.

12. Rincon F, Kang J, Maltenfort M, Vibbert M, Urtecho J, Athar MK, Jallo J, Pineda CC, Tzeng D, McBride W, Bell R: Association between hyperoxia and mortality after stroke: a multicenter cohort study. Crit Care Med 2014, 42:387-396.

13. Rincon F, Kang J, Vibbert M, Urtecho J, Athar MK, Jallo J: Significance of arterial hyperoxia and relationship with case fatality in traumatic brain injury: a multicentre cohort study. J Neurol Neurosurg Psychiatry 2014, 85:799-805.

14. Adrie C, Adib-Conquy M, Laurent I, Monchi M, Vinsonneau C, Fitting C, Fraisse F, Dinh-Xuan AT, Carli P, Spaulding C, Dhainaut JF, Cavaillon JM: Successful cardiopulmonary resuscitation after cardiac arrest as a 'sepsis-like' syndrome. Circulation 2002, 106:562-568.

15. Polderman $\mathrm{KH}$ : Mechanisms of action, physiological effects, and complications of hypothermia. Crit Care Med 2009, 37:S186-S202.

16. Small DL, Morley P, Buchan AM: Biology of ischemic cerebral cell death. Prog Cardiovasc Dis 1999, 42:185-207.

17. Globus MY, Busto $R$, Lin B, Schnippering $H$, Ginsberg MD: Detection of free radical activity during transient global ischemia and recirculation: effects of intraischemic brain temperature modulation. J Neurochem 1995, 65:1250-1256.

18. Cornet AD, Kooter AJ, Peters MJ, Smulders YM: The potential harm of oxygen therapy in medical emergencies. Crit Care 2013, 17:313.

19. Neumar RW: Optimal oxygenation during and after cardiopulmonary resuscitation. Curr Opin Crit Care 2011, 17:236-240.

20. Meyhoff CS, Staehr AK, Rasmussen LS: Rational use of oxygen in medical disease and anesthesia. Curr Opin Anaesthesiol 2012, 25:363-370.

21. Hazelton JL, Balan I, Elmer Gl, Kristian T, Rosenthal RE, Krause G, Sanderson $\mathrm{TH}$, Fiskum G: Hyperoxic reperfusion after global cerebral ischemia promotes inflammation and long-term hippocampal neuronal death. J Neurotrauma 2010, 27:753-762.

22. Floyd TF, Clark JM, Gelfand R, Detre JA, Ratcliffe S, Guvakov D, Lambertsen CJ, Eckenhoff RG: Independent cerebral vasoconstrictive effects of hyperoxia and accompanying arterial hypocapnia at 1 ATA. J App Physiol 2003, 95:2453-2461.

23. Morimoto T, Fukuda M, Aibara Y, Nagao H, Kida K: The influence of blood gas changes on hyperthermia-induced seizures in developing rats. Brain Res Dev Brain Res 1996, 92:77-80.

24. Pilla R, Landon CS, Dean JB: A potential early physiological marker for CNS oxygen toxicity: hyperoxic hyperpnea precedes seizure in unanesthetized rats breathing hyperbaric oxygen. J App Physiol 2013, 114:1009-1020.

25. Pilcher J, Weatherall M, Shirtcliffe P, Bellomo R, Young P, Beasley R: The effect of hyperoxia following cardiac arrest - a systematic review and meta-analysis of animal trials. Resuscitation 2012, 83:417-422.

26. Spindelboeck W, Schindler O, Moser A, Hausler F, Wallner S, Strasser C, Haas J, Gemes G, Prause G: Increasing arterial oxygen partial pressure during cardiopulmonary resuscitation is associated with improved rates of hospital admission. Resuscitation 2013, 84:770-775.

27. Kuisma M, Boyd J, Voipio V, Alaspaa A, Roine RO, Rosenberg P: Comparison of 30 and the $100 \%$ inspired oxygen concentrations during early post-resuscitation period: a randomised controlled pilot study. Resuscitation 2006, 69:199-206.

28. Kilgannon JH, Jones AE, Shapiro NI, Angelos MG, Milcarek B, Hunter K, Parrillo JE, Trzeciak S, Emergency Medicine Shock Research Network (EMShockNet) Investigators: Association between arterial hyperoxia following resuscitation from cardiac arrest and in-hospital mortality. JAMA 2010, 303:2165-2171.

29. Kilgannon JH, Jones AE, Parrillo JE, Dellinger RP, Milcarek B, Hunter K, Shapiro NI, Trzeciak S, Emergency Medicine Shock Research Network (EMShockNet) Investigators: Relationship between supranormal oxygen tension and outcome after resuscitation from cardiac arrest. Circulation 2011, 123:2717-2722.

30. Cummins RO, Chamberlain DA, Abramson NS, Allen M, Baskett PJ, Becker L, Bossaert L, Delooz HH, Dick WF, Eisenberg MS: Recommended guidelines for uniform reporting of data from out-of-hospital cardiac arrest: the 
Utstein Style. A statement for health professionals from a task force of the American Heart Association, the European Resuscitation Council, the Heart and Stroke Foundation of Canada, and the Australian Resuscitation Council. Circulation 1991, 84:960-975.

31. Bellomo R, Bailey M, Eastwood GM, Nichol A, Pilcher D, Hart GK, Reade MC, Egi M, Cooper DJ, Study of Oxygen in Critical Care (SOCC) Group: Arterial hyperoxia and in-hospital mortality after resuscitation from cardiac arrest. Crit Care 2011, 15:R90.

32. Janz DR, Hollenbeck RD, Pollock JS, McPherson JA, Rice TW: Hyperoxia is associated with increased mortality in patients treated with mild therapeutic hypothermia after sudden cardiac arrest. Crit Care Med 2012, 40:3135-3139.

33. Ihle JF, Bernard S, Bailey MJ, Pilcher DV, Smith K, Scheinkestel CD: Hyperoxia in the intensive care unit and outcome after out-of-hospital ventricular fibrillation cardiac arrest. Crit Care Resusc 2013, 15:186-190.

34. Lee BK, Jeung KW, Lee HY, Lee SJ, Jung YH, Lee WK, Heo T, Min YI: Association between mean arterial blood gas tension and outcome in cardiac arrest patients treated with therapeutic hypothermia. Am J Emerg Med 2014, 32:55-60

35. Vaahersalo J, Bendel S, Reinikainen M, Kurola J, Tiainen M, Raj R, Pettilä V, Varpula T, Skrifvars MB, FINNRESUSCI Study Group: Arterial blood gas tensions after resuscitation from out-of-hospital cardiac arrest: associations with long-term neurologic outcome. Crit Care Med 2014, 42:1463-1470.

36. Peberdy MA, Callaway CW, Neumar RW, Geocadin RG, Zimmerman JL, Donnino M, Gabrielli A, Silvers SM, Zaritsky AL, Merchant R, Vanden Hoek TL, Kronick SL: Part 9: post-cardiac arrest care: 2010 American Heart Association Guidelines for Cardiopulmonary Resuscitation and Emergency Cardiovascular Care. Circulation 2010, 122:S768-S786.

37. Deakin CD, Nolan JP, Soar J, Sunde K, Koster RW, Smith GB, Perkins GD: European Resuscitation Council Guidelines for Resuscitation 2010 Section 4. Adult Adv Life Support Resusc 2010, 81:1305-1352.

38. Nelskyla A, Parr MJ, Skrifvars MB: Prevalence and factors correlating with hyperoxia exposure following cardiac arrest - an observational single centre study. Scand J Trauma Resusc Emerg Med 2013, 21:35.

39. Schneider AG, Eastwood GM, Bellomo R, Bailey M, Lipcsey M, Pilcher D, Young P, Stow P, Santamaria J, Stachowski E, Suzuki S, Woinarski NC, Pilcher J: Arterial carbon dioxide tension and outcome in patients admitted to the intensive care unit after cardiac arrest. Resuscitation 2013, 84:927-934.

40. Ganga HV, Kallur KR, Patel NB, Sawyer KN, Gowd PB, Nair SU, Puppala VK, Manandhi AR, Gupta AV, Lundbye JB: The impact of severe acidemia on neurologic outcome of cardiac arrest survivors undergoing therapeutic hypothermia. Resuscitation 2013, 84:1723-1727.

doi:10.1186/s13054-014-0555-4

Cite this article as: Dell'Anna et al:: How much oxygen in adult cardiac arrest? Critical Care 2014 18:555. 